\title{
EFFECT OF SUPPLEMENTATION OF AROMATIC PLANTS OILS ON IMMUNITY, UDDER HEALTH AND MILK PRODUCTION OF FRIESIAN cows
}

\author{
Atef Y. Salem ${ }^{1 *}$, Hassan G. El-Awady ${ }^{1}$, Mohamed A. Tag EL-Dein², Dina A. Eisa \\ ${ }^{1}$ Department of Animal Production, Faculty of Agriculture, Kafrelsheikh University 33516, Egypt, \\ ${ }^{2}$ Animal Production Research Institute, Egypt \\ *Corresponding author, E-Mail: dinaeisa2030@gmail.com
}

\begin{abstract}
Eight weeks prior to expected calving date, 32 Friesian cows were assigned according to parity to four homogenous groups (8 animals each). Cows were fed a basal ration alone as a control group 1 (CON G1), or basal ration supplemented with $25 \mathrm{mg}$ black seed oil per $\mathrm{kg}$ body weight, (BSO G2), $11 \mathrm{mg}$ chamomile flower oil (CFO G3), or $25 \mathrm{mg}$ oregano leaves oil (OLO G4). Biochemical and hematological parameters were measured and there were within the normal ranges of cattle. Relative to the control group, aromatic plant oils significantly reduced plasma lipids and increased plasma concentration of IgG. Feed intake was similar among groups. Economic evaluations were in favor of BSO group. BSO significantly $(\mathrm{P}<0.05)$ improved daily milk yield (DMY), fat and protein, but reduced lactose content of milk. CFO increased $(P<0.05)$ daily milk yield. Only fatcorrected DMY was increased with OLO supplementation. The three supplements reduced $(P<0.05)$ milk electric conductivity $(E C)$ and somatic cell count $(S C C)$. Overall, our results indicated that supplementing diets of Friesian cows with aromatic plant oils, particularly black seed oil, improved milk yield, udder health, and some immune parameters.
\end{abstract}

Key words: aromatic oils; cows; blood parameters; milk production and immunity

\section{Introduction}

Essential oils are a diverse group of secondary plant metabolites that contain naturally occurring volatile components that support smell and taste of plants (1). The volatile aromatic compounds have an oily appearance and they are extracted from plants (2). As a product, they are extracted from a plant or some parts through hydrodistillation, steam distillation, or dry distillation, without heating by a mechanical process (3). Essential oils have unique properties and offer a huge potential benefit for animal performance. One potential benefit that gained a lot attention is the antibacterial properties of these compounds. There is interest that essential oils could be a potential approach to improve feed efficiency, nutrient utilization, and animal health as an alternative to antibiotics. However, at this point we still need further research to provide information for practical feeding recommendations.

Fatty acids, volatile oils and trace elements combination contributes black seed effectiveness. Little is known about the activity of volatile oil in $\mathrm{N}$. sativa (4). Black seed oil (Nigella sativa) contains a substance called Nigellone which is a natural antioxidant that can modulate and regulate the early activation steps in the acquired immune response (5). 
Oregano (Origanum vulgare L.) is an herb with high antioxidant capacity-compared to several other medicinal herbs $(6,7)$. Oregano oil can be defined as plant extract that contains mainly carvacrol and thymol, which are the major phenols constitute about $78-82 \%$ of essential oil. Moreover, it has antifungal (8) and antimicrobial properties (9) which make it an appropriate organic alternative for antibiotic as well as a promising feed additive in order to prevent meat lipid oxidation (10). Furthermore, $50 \%$ of essential oil of chamomile flowers (Chamomila recutita) contains alphabisabolol (trepenoid) and azulene these compounds showed anti-inflammatory, antibacterial, antimycotic and ulcer protective properties (11). Electrical conductivity (EC) of milk was indicator parameter for mastitis and is measured by the presence of ions (12). The current work was amid to effects of black seed, oregano and chamomile oil supplementation on blood parameters, immunity, udder health, and yield and composition of milk of lactating Friesian cows.

\section{Materials and methods}

This study was carried out at Sakha Animal Production Research Station, belonging to Animal Production Research Institute (APRI), Agricultural Research Center, Ministry of Agriculture, Egypt.

\section{Animals and experimental groups}

Thirty-two Friesian cows with live body weight (LBW) of $547.50 \pm 15.75 \mathrm{~kg}$ at eight weeks before parturition were classification into four groups ( 8 each) there to LBW and season of lactation $\left(2^{\text {nd }}\right.$ to $\left.8^{\text {th }}\right)$ continued until four months postpartum. Cows fed a basal ration contained (on DM basis) $40 \%$ concentrate feed mixture (CFM), 25\% fresh berseem (FB), 20\% corn silage (CS) and $15 \%$ rice straw (RS) without any supplement in G1, which was served as control. The ration was supplemented with $25 \mathrm{mg}$ black seeds oil (5) per $\mathrm{kg} \mathrm{LBW}$ in $\mathrm{G} 2$ (13), $11 \mathrm{mg}$ chamomile flower oil (14) per kg LBW in G3 (15) and 25 mg oregano leaves oil (16) per kg LBW in G4
(17). Composition of feedstuffs and calculated composition were show in Table (1). The CFM composed of $20 \%$ soybean meal, $24 \%$ wheat bran, $34 \%$ yellow corn, $12 \%$ rice bran, $5 \%$ linseed, $3 \%$ molasses, $0.5 \%$ premix and $1.5 \%$ common salt. Chemical analysis of samples of feedstuffs, were carried out according to the methods A.O.A.C (18).

\section{Management}

Cows housed in semi-open backyards under sheds and were fed their rations to cover their recommended requirements (19). The CFM was offered two parts at 8 a.m. and 4 p.m. daily. All cows had free access to fresh drinking water throughout the day.

\section{Samples of milk yield (MY)}

Animals were machine milked twice daily at 6 a.m. and 5 p.m. Daily milk yield was recorded individually and corrected for $4 \%$ fat contact (FCM): $4 \% \mathrm{FCM}=0.4 \times \mathrm{MY}(\mathrm{kg})+$ $15 \mathrm{x}$ fat yield (kg) (20). Milk samples were taken from cows every two weeks and were analyzed for milk composition by Milko-Scan (model 133B). Milks of EC were measured for all quarter using "Dramtnski Electronic in agriculture, Mastitis detection, Italy". Furthermore, SCC analyzed milk sample with a Fossomatic 5000 "Foss Electric A S 69, Slangerupgade DK 3400 Hilleroed, Denmark Comp".

\section{Samples of blood}

Samples of blood were taken all cows before partition at days 45, 30 and 15 and after partition at $7^{\text {th }}$ day. Blood samples were taken from the jugular vein by clean sterile needle in the clean dry plastic tube after 4 hours from the morning feeding in two parts. First part centrifuged at 4000 r.p.m for $15 \mathrm{~min}$ and stored at $-20^{\circ} \mathrm{C}$. Some boichemical parameters of blood were determined calorimetrically by using commercial kits (Diagnostic System Laboratories, Inc., USA). Second part used for determining hematological parameters in whole blood samples with EDTA (anticoagulant). Hematological analysis was performed by Medici Vet. (21). Hematological 
analysis (Medonic CA 620, Sweden) was performed within 1-2 hrs after samples collection. Hematological variables were red blood cells (RBC's), hemoglobin (HGB), hematocrit (HCT), platelet (PLT). Leucocyte variables were white blood cells (WBC's) and differential white cells (lymphocytes, monocytes and neutrophils). The concentration of immunoglobulin $\mathrm{G}(\mathrm{IgG})$ in the blood serum samples determined using the quantitative ELISA Bovine (IgG), ELISA Quantitation Kit, Bethyl laboratories, UK.

\section{Economic evaluation}

Economic efficiency calculated between the price of milk yield 4\% FCM and the cost of daily feeding consumed. The prices in Egyptian pound (LE) per ton were $4750 \mathrm{LE}$ for CFM, $320 \mathrm{LE}$ for fresh berseem, $690 \mathrm{LE}$ for corn silage and $250 \mathrm{LE}$ for rice straw. Also, the prices per kg were $110 \mathrm{LE}$ for black seed oil, $90 \mathrm{LE}$ for chamomile oil, $90 \mathrm{LE}$ for oregano oil and 5 LE for 4\% FCM produced during year 2017.

\section{Statistical analysis}

The obtained data were statistically analyzed system using SAS (22). One way ANOVA was used. The significant differences among treatment groups were using Duncan's New Multiple Ranges Test (23).

Table 1: Chemical composition and calculated feeding values of feed ingredients and basal ration.

\begin{tabular}{lccccccccc}
\hline \multirow{2}{*}{ Item } & \multirow{2}{*}{ DM \% } & \multicolumn{4}{c}{ Composition of DM \% } & \multicolumn{3}{c}{ Calculated \% } \\
\cline { 3 - 10 } & & OM & CP & CF & EE & NFE & Ash & TDN & DCP \\
\hline CFM & 91.01 & 91.48 & 16.52 & 8.37 & 2.46 & 64.13 & 8.52 & 68.9 & 12.8 \\
Fresh berseem & 20.01 & 91.19 & 15.63 & 24.54 & 2.88 & 48.21 & 8.83 & 64.4 & 12.6 \\
Corn silage & 33.60 & 90.97 & 9.45 & 17.32 & 2.55 & 61.65 & 9.03 & 69.9 & 8.4 \\
Rice straw & 90.30 & 83.59 & 2.56 & 31.79 & 1.09 & 48.15 & 16.41 & 48.2 & 0.5 \\
Basal ration & 61.67 & 90.12 & 12.79 & 17.72 & 2.37 & 57.24 & 9.88 & 64.87 & 10.03 \\
\hline
\end{tabular}

DM: dry matter; OM: organic matter CP: crude protein; CF: crude fiber; EE: ether extract; NFE: nitrogen free extract; TDN: total digestible nutrients; DCP: digestive protein. CFM: Concentrate feed mixture

Table 2: Blood serum biochemicals of cows supplemented with aromatic plant oils.

\begin{tabular}{lcccc}
\hline & \multicolumn{4}{c}{ Experimental groups } \\
\cline { 2 - 5 } Item & $\mathrm{G} 1$ & $\mathrm{G} 2$ & $\mathrm{G} 3$ & $\mathrm{G} 4$ \\
\hline Total protein $(\mathrm{g} / \mathrm{dl})$ & $5.90 \pm 0.43^{\mathrm{b}}$ & $7.55 \pm 0.32^{\mathrm{a}}$ & $6.83 \pm 0.15^{\mathrm{ab}}$ & $6.82 \pm 0.33^{\mathrm{ab}}$ \\
Albumin $(\mathrm{g} / \mathrm{dl})$ & $3.78 \pm 0.21^{\mathrm{a}}$ & $3.54 \pm 0.11^{\mathrm{b}}$ & $3.56 \pm 0.11^{\mathrm{ab}}$ & $3.64 \pm 0.14^{\mathrm{a}}$ \\
Globulin $(\mathrm{g} / \mathrm{dl})$ & $2.50 \pm 0.16^{\mathrm{b}}$ & $4.10 \pm 0.28^{\mathrm{b}}$ & $3.27 \pm 0.21^{\mathrm{b}}$ & $3.06 \pm 0.35^{\mathrm{b}}$ \\
Total lipids (mg/dl) & $221.0 \pm 0.46^{\mathrm{a}}$ & $191.0 \pm 0.29^{\mathrm{b}}$ & $184.0 \pm 0.43^{\mathrm{c}}$ & $183.0 \pm 0.40^{\mathrm{c}}$ \\
Cholesterol (mg/dl) & $71.6 \pm 0.32^{\mathrm{a}}$ & $68.9 \pm 0.17^{\mathrm{b}}$ & $65.5 \pm 0.24^{\mathrm{c}}$ & $64.0 \pm 0.21^{\mathrm{d}}$ \\
Triglyceride (mg/dl) & $93.0 \pm 0.21^{\mathrm{a}}$ & $87.8 \pm 0.21^{\mathrm{b}}$ & $84.8 \pm 0.18^{\mathrm{c}}$ & $83.7 \pm 0.18^{\mathrm{c}}$ \\
IgG (mg/ml) & $37.4 \pm 0.93^{\mathrm{b}}$ & $50.9 \pm 3.96^{\mathrm{a}}$ & $46.5 \pm 3.70^{\mathrm{a}}$ & $45.7 \pm 1.45^{\mathrm{a}}$ \\
\hline
\end{tabular}

Values are represented as the mean $\pm \mathrm{SE}$.

${ }^{a b c}$ Within-row different superscript letters denote significant difference $(\mathrm{P}<0.05)$.

G1: basal diet. G2: basal diet supplemented with $25 \mathrm{mg}$ black seed oil per kg body weight.G3: basal diet supplemented with $11 \mathrm{mg}$ chamomile oil per kg body weight.G4: basal diet supplemented with $25 \mathrm{mg}$ oregano oil per $\mathrm{kg}$ body weight. 
Table 3: Blood hematological parameters of cows supplemented with aromatic plant oils

\begin{tabular}{lcccc}
\hline & \multicolumn{4}{c}{ Experimental groups } \\
\cline { 2 - 5 } Item & $\mathrm{G} 1$ & $\mathrm{G} 2$ & $\mathrm{G} 3$ & $\mathrm{G} 4$ \\
\hline WBC's $\left(10^{3} / \mu \mathrm{l}\right)$ & $9.63 \pm 0.36^{\mathrm{c}}$ & $13.7 \pm 0.89^{\mathrm{a}}$ & $11.6 \pm 0.41^{\mathrm{b}}$ & $11.2 \pm 0.92^{\mathrm{b}}$ \\
Lymphocytes \% & $52.02 \pm 0.44^{\mathrm{c}}$ & $58.1 \pm 0.88^{\mathrm{a}}$ & $54.7 \pm 1.72^{\mathrm{b}}$ & $52.7 \pm 1.72^{\mathrm{c}}$ \\
Monocytes \% & $6.96 \pm 0.17^{\mathrm{b}}$ & $8.93 \pm 0.58^{\mathrm{a}}$ & $7.33 \pm 0.81^{\mathrm{ab}}$ & $7.63 \pm 0.49^{\mathrm{b}}$ \\
Neutrophils \% & $26.9 \pm 0.32^{\mathrm{c}}$ & $31.5 \pm 1.84^{\mathrm{a}}$ & $29.7 \pm 2.01^{\mathrm{b}}$ & $28.2 \pm 2.25^{\mathrm{b}}$ \\
PLT $\left(10^{3} / \mu \mathrm{l}\right)$ & $108.0 \pm 2.72^{\mathrm{d}}$ & $185.0 \pm 6.48^{\mathrm{a}}$ & $168.0 \pm 6.75^{\mathrm{b}}$ & $152.0 \pm 3.07^{\mathrm{c}}$ \\
RBCs $\left(10^{6} / \mu \mathrm{l}\right)$ & $6.34 \pm 0.32$ & $6.46 \pm 0.19$ & $6.32 \pm 0.40$ & $6.10 \pm 0.36$ \\
Hgb $(\mathrm{g} / \mathrm{dl})$ & $10.7 \pm 0.72$ & $12.7 \pm 0.72$ & $12.5 \pm 1.02$ & $12.2 \pm 0.32$ \\
HCT $(\%)$ & $28.9 \pm 0.53^{\mathrm{b}}$ & $31.5 \pm 0.53^{\mathrm{a}}$ & $30.1 \pm 0.87^{\mathrm{ab}}$ & $29.5 \pm 0.80^{\mathrm{ab}}$ \\
\hline
\end{tabular}

Values are represented as the mean \pm SE.

${ }^{a}$ Different superscript letters within the same row denote significant difference $(\mathrm{P}<0.05)$.

G1: basal diet. G2: basal diet supplemented with $25 \mathrm{mg}$ black seed oil per kg body weight. G3: basal diet supplemented with $11 \mathrm{mg}$ chamomile oil per kg body weight. G4: basal diet supplemented with $25 \mathrm{mg}$ oregano oil per kg body weight. WBCs: PLT: platelets; RBCs: Hgb: Hemoglobin; HCT: hematocrit

Table 4: Average actual yield, milk composition, electric conductivity and somatic cells count of cow's milk supplemented with aromatic plant oils

\begin{tabular}{lcccc}
\hline & \multicolumn{4}{c}{ Experimental groups } \\
\cline { 2 - 5 } Item & $\mathrm{G} 1$ & $\mathrm{G} 2$ & $\mathrm{G} 3$ & $\mathrm{G} 4$ \\
\hline Actual yield, kg/day & $12.9 \pm 0.25^{\mathrm{b}}$ & $15 \pm 0.35^{\mathrm{a}}$ & $14.5 \pm 0.24^{\mathrm{a}}$ & $14.1 \pm 0.30^{\mathrm{ab}}$ \\
Fat corrected milk yield, kg/day & $12.3 \pm 0.28^{\mathrm{c}}$ & $15.9 \pm 0.34^{\mathrm{a}}$ & $14.8 \pm 0.53^{\mathrm{ab}}$ & $14.2 \pm 0.48^{\mathrm{b}}$ \\
Fat\% & $3.66 \pm 0.11^{\mathrm{b}}$ & $4.42 \pm 0.13^{\mathrm{a}}$ & $4.15 \pm 0.19^{\mathrm{ab}}$ & $4.03 \pm 17^{\mathrm{ab}}$ \\
Protein, \% & $3.01 \pm 0.03^{\mathrm{b}}$ & $3.11 \pm 0.11^{\mathrm{a}}$ & $3.03 \pm .05^{\mathrm{b}}$ & $3.06 \pm .07^{\mathrm{ab}}$ \\
Lactose, \% & $4.85 \pm 0.09^{\mathrm{a}}$ & $4.19 \pm 0.12^{\mathrm{b}}$ & $4.20 \pm 0.14^{\mathrm{ab}}$ & $4.32 \pm 0.19^{\mathrm{a}}$ \\
Electrical conductivity, MS/ml & $5.59 \pm 0.02^{\mathrm{a}}$ & $5.21 \pm 0.11^{\mathrm{b}}$ & $5.26 \pm 0.06^{\mathrm{b}}$ & $5.26 \pm 0.07^{\mathrm{b}}$ \\
Somatic cells count, $10^{3} / \mathrm{ml}$ & $393 \pm 3.65^{\mathrm{a}}$ & $162 \pm 5.96^{\mathrm{c}}$ & $178 \pm 2.61^{\mathrm{b}}$ & $183 \pm 2.01^{\mathrm{b}}$ \\
\hline
\end{tabular}

Values are represented as the mean \pm SE.

Different superscript letters within the same row denote significant difference $(\mathrm{P}<0.05)$.

G1: basal diet. G2: basal diet supplemented with $25 \mathrm{mg}$ black seed oil per $\mathrm{kg}$ body weight.G3: basal diet supplemented with $11 \mathrm{mg}$ chamomile oil per kg body weight.G4: basal diet supplemented with $25 \mathrm{mg}$ oregano oil per kg body weight.

Table 5: Feed intake and economic efficiency of cows in different experimental groups

\begin{tabular}{lcccc}
\hline & \multicolumn{4}{c}{ Experimental groups } \\
\cline { 2 - 5 } Item & $\mathrm{G} 1$ & $\mathrm{G} 2$ & $\mathrm{G} 3$ & $\mathrm{G} 4$ \\
\hline Total DM intake (kg/day) & $17.64 \pm 0.32$ & $17.73 \pm 0.35$ & $17.77 \pm 0.34$ & $17.75 \pm 0.41$ \\
Feed cost (LE/day) & $51.69 \pm 0.56$ & $51.94 \pm 0.54$ & $52.06 \pm 0.57$ & $52.00 \pm 0.50$ \\
Feed cost (LE/kg FCM) & $4.24 \pm 0.03^{\mathrm{a}}$ & $3.26 \pm 0.04^{\mathrm{c}}$ & $3.53 \pm 0.07^{\mathrm{b}}$ & $3.66 \pm 0.05^{\mathrm{b}}$ \\
Total revenue (LE/day) & $60.85 \pm 0.74^{\mathrm{c}}$ & $79.65 \pm 0.68^{\mathrm{a}}$ & $73.80 \pm 0.65^{\mathrm{b}}$ & $71.05 \pm 0.75^{\mathrm{b}}$ \\
Net revenue (LE/day) & $9.16 \pm 0.10^{\mathrm{c}}$ & $27.71 \pm 0.08^{\mathrm{a}}$ & $21.74 \pm 0.11^{\mathrm{b}}$ & $19.05 \pm 0.09^{\mathrm{b}}$ \\
Economic efficiency & $1.18 \pm 0.02^{\mathrm{b}}$ & $1.53 \pm 0.03^{\mathrm{a}}$ & $1.42 \pm 0.04^{\mathrm{ab}}$ & $1.37 \pm 0.03^{\mathrm{ab}}$ \\
Relative EE \% & $100.00 \pm 2.54^{\mathrm{b}}$ & $129.66 \pm 1.89^{\mathrm{a}}$ & $120.34 \pm 2.15^{\mathrm{ab}}$ & $116.10 \pm 2.28^{\mathrm{ab}}$ \\
\hline
\end{tabular}

Different superscript letters within the same row denote significant difference $(\mathrm{P}<0.05)$.

G1: basal diet. G2: basal diet supplemented with $25 \mathrm{mg}$ black seed oil per kg body weight.G3: basal diet supplemented with $11 \mathrm{mg}$ chamomile oil per kg body weight.G4: basal diet supplemented with $25 \mathrm{mg}$ oregano oil per kg body weight. 


\section{Results and discussion}

\section{Blood parameters}

Blood serum biochemical of cows in experimental groups Table (2) showed that G2 had the higher concentrations of total protein and globulin in serum (7.55- $4.10 \mathrm{~g} / \mathrm{dl})$ followed by G3 (6.83-3.27 g/dl) and G4 (6.82$3.06 \mathrm{~g} / \mathrm{dl})$, while G1 (5.90- $2.50 \mathrm{~g} / \mathrm{dl})$ had the lowest values. However, G1 recorded the higher concentrations of albumin, total lipids, cholesterol and triglycerides, but G2 had the lowest albumin and G4 had the lowest total lipids, cholesterol and triglycerides concentrations. Results cleared that BSO supplementation increased the concentrations of total protein and globulin in serum. Oregano oil (OLO) decreased the concentrations of total lipids, cholesterol and triglycerides. The increasing of total protein and lipids in treatments may be due to that aromatic oil increased digestibility coefficients of crud protein and lipids. Blood total protein and their fractions can be used as indicators to evaluate the ruminant nutritional status and physiological changes (24). Moreover, immunoglobulin $\mathrm{G}(\mathrm{IgG})$ was higher significantly $(\mathrm{P}<0.05)$ in G2 $(50.9 \mathrm{mg} / \mathrm{ml}), \mathrm{G} 3(46.5 \mathrm{mg} / \mathrm{ml})$ and G4 $(45.7 \mathrm{mg} / \mathrm{ml})$, whereas $\mathrm{G} 1(37.4 \mathrm{mg} / \mathrm{ml})$ had the lowest concentration which attributed to contains of minerals and vitamins, which may have a role in improvement immunoglobulin and immunity response (22). Concentrations of total protein, albumin, globulin and glucose in blood serum were higher of animals received chamomile flower, garlic and fenugreek seeds comparison with the control one (26). Plasma total protein, albumin, and plasma immunoglobulin tended to higher $(\mathrm{P}<0.05)$ in lactating buffaloes received $10 \mathrm{ml}$ $\mathrm{BSO} /$ head/day (13). Polyherbal supplementation at the rate of $200-250 \mathrm{mg} / \mathrm{kg}$ body weight improved immunity (27).

Blood hematological parameters of Friesian cows in experimental groups are presented in Table (3). Cows in G2 supplemented with black seed oil showed highest $(\mathrm{P}<0.05)$ total WBC's count and relative percentages of lymphocytes, monocytes and neutrophils
(13.7, 58.1, 8.93 and31.5\%), followed by G3 $(11.6,54.7,7.33$ and $29.7 \%)$ and $\mathrm{G} 4$ (11.2, $52.7,7.63,28.2 \%)$, whereas G1 $(9.63,52.02$, 6.96 and $26.9 \%$ ) had the lowest values. The increase of immunoglobulin could be credited to B-lymphocyte stimulation (28). The WBCs are soldiers of body and their high counts may be due to increase or development of the immune systems of the animals and the lymphocytes constituted majority of WBCs counts and the cells increase with age in early life of animals (23).

Also, G2 had the higher PLT count and HCT $\left(18510^{3} / \mu 1\right.$ and $\left.31.5 \%\right)$ followed by G3 $\left(16810^{3} / \mu 1\right.$ and $\left.30.1 \%\right)$ and G4 $\left(15210^{3} / \mu 1\right.$ and $29.5 \%$ ), but the lowest values were in G1 (108 $10^{3} / \mu 1$ and 28. 9\%). While RBC's and $\mathrm{Hgb}$ was nearly similar for the different groups and not significantly affected by oil supplementation. It is clear that black seed oil (G2) was more effective in blood hematological parameters than chamomile oil (G3) and oregano oil (G4). Blood hematological profile reflects the physiological response of the cow to its external environments and internal with by feeding and feeds (29). Package cell value significantly increase $(\mathrm{P}>0.05)$ with $10 \mathrm{ml}$ (BSO)/head/day of lactating buffaloes (13). Addition of medicinal plant CF significantly increased total RBC's and $\mathrm{Hb}$ concentration in lamb's blood (30). Black seed (Nigella sativa) contains minerals and vitamins which may have a vital role improving immune system and improve of formation and maturation of RBC's count $(13,25)$.

\section{Milk production}

Actual and 4\% FCM yield (Kg/day) for cows of the experimental groups (Table 4) significantly $(\mathrm{P}<0.05)$ among groups, which have higher in G2 $(15,15.9)$ followed by G3 $(14.5,14.8)$ and $\mathrm{G} 4(14.1,14.2)$, while were lower in G1 $(12.9,14.2)$. Superiority of G2, G3 and G4 compared to G1 in milk production and fat corrected milk as affected by the galactogoetic, which have the positive effect of the active components that aromatic oils may contain (30). Oregano leaf had little increase $3.5 \%$ FCM yield in dairy cattle (16). 
Milk compositions of cows in experimental groups were presented in Table (4). Results indicated that G2 significantly higher $(\mathrm{P}<0.05)$ contents of fat and protein $(4.42$ and $3.11 \%)$, followed by G3 (4.12 and $3.03 \%$ ) and G4 (4.03 and $3.06 \%$ ), but G1 (3.66 and $3.01 \%$ ) had the lowest contents. The increasing of total protein and fat in milk due to the high contain of them on blood plasma; this declares the positive correlation between them.

While, lactose mean was nearly similar in each group. In general, aromatic plant oils supplementation especially BSO improved milk composition of Friesian cows, which might due to improve the udder health. Treatment with NS was improvement milk yield and lactose in buffaloes than in the control and recorded slight increase in milk protein percentage (31). The use of CF and NSS 10 $\mathrm{g} /$ ewe/day as natural feed additives increased $(\mathrm{P}<0.05)$ total protein $(\mathrm{TP})$. But, lactose not effects in CF or NSS supplementation (30).

\section{Udder health}

Aromatic plant oils led to significantly lowest $(\mathrm{P}<0.05)$ in EC and SCC than in control Table (4). Black seed oil (BSO) supplement showed the lowest values of electrical conductivity and somatic cells count. The EC of milk has a positive correlation with somatic cell count. The infection with clinical mastitis increased in Friesian cows with the increase of somatic cell count levels (33). The values of EC in our study ranged (5.59 - 5.21 $\mathrm{MS} / \mathrm{ml}$ ) and are within EC of healthy cow milk is 4.0-5.5 milisenses (MS)/cm $(12,34)$. $\mathrm{EC}$ is used as routine test for sub clinical mastitis diagnosis (35) The EC determined anions and cations $\left(\mathrm{Na}^{+}\right.$and $\left.\mathrm{Cl}^{-}\right)$ions concentrations increased and $\mathrm{K}+$ concentration and lactose decreased when the cows and buffalos were suffering with mastitis due to inflammation of udder hence increase the EC. Although EC is also affected by some other factors such as bread, lactation stage and milking interval (36). Polyherbal treated at the rate of 200-250 $\mathrm{mg} / \mathrm{kg}$ live weight improved udder health (27).

\section{Economic efficiency}

Feed intake and economic efficiency of cows in experimental groups were presented in Table (5). Total DM intake from the different rations was nearly similar for the different groups indicating that aromatic plant oils supplementation don't have any adverse effect on feed intake. Also, the costs of feed intake were similar for all groups, whereas G2 only significantly $(\mathrm{P}<0.05)$ lower feed cost per $\mathrm{kg}$ $4 \%$ FCM compared to G1 had the higher value, while G3 and G4 were intermediate between them. However, G2 recorded significantly $(\mathrm{P}<0.05)$ highest values of total revenue of $4 \%$ fat corrected milk, net revenue, economic efficiency and relative economic efficiency, followed by G3 and G4, but G1 had the lowest values. The improvements in economic efficiency with aromatic plant oils supplementation might be due to the increase of both actual fat and $4 \%$ fat corrected milk yield. Black seed and pumpkin oils supplementation for growing rabbits didn't affected feed cost, but significantly $(\mathrm{P}<0.05)$ increased total and net revenue (37).

\section{Conclusion}

These results concluded that aromatic plant oils additives to diets of dairy cows improve production and milk composition, udder health and immunity as well as economic efficiency and that best results obtained was with black seeds oil.

\section{Disclosure statement}

The authors declare that they have no conflict of interest.

\section{References}

1. Calsamiglia S, Busquet M, Cardozo PW, Castillejos L, Ferret A. Invited Review: Essential oils as modifiers of rumen microbial fermentation. J. Dairy Sci., 2007; 90: 2580-95.

2. Tassoul MD, Shaver RD. Effect of a mixture of supplemental dietary plant essential oils on performance of periparturient and early lactation dairy cows. J. Dairy Sci. 2009; 92: 1734-1740.

3. Miguel MG. Antioxidant and anti-inflammatory activities of essential oils: a short review. Molecules, 2010; 15: 9252-87. 
4. El-Kamali HH, Ahmad AH, Mohammad AS, Yahia AAM. Antibacterial properties of essentials oils from Nigella sativa. Fitoterapia, 1998; 69: 77-8.

5. Abd El-Hafeez AM, Ali MAE, Abu ElHamd MA, Wahba AA And Kamla M. El-Sayed. Productive Performance, Immune Status And Metabolic Activity Of Suckling Bovine Calves Treated With Nigella Sativa Oil. Egypt. J. Agric. Res., 2014; 92 (4).

6. Dragland S, Senoo H, Wake K, Holte K, Blomhoff R. Several culinary and medicinal herbs are important sources of dietary antioxidants. J. Nutr., 2003; 133: 1286-90.

7. Matsuura H, Chiji H, Asakawa C, Amano M, Yoshihara T, Mizutani J. DPPH radical scavengers from dried leaves of oregano (Origanum vulgare). Biosci. Biotechnol. Biochem., 2003; 67: 2311-6.

8. Daouk R, Dagher SM, Sattout E. Antifungal activity of the essential of Driganum syriacum L. Journal of Food Protection, 1995; 58(10): 11479.

9. Dorman HJD, Deans SG. Antimicrobial agents from plants: antimicrobial activity of plant volatile oils. J. Appl. Microbiol., 2000; 88: 30816.

10. Simitzis PE, Deligeorgis SG, Bizelis JA, Dardamani A, Theodosiou I, Feggeros K. Effect of dietary oregano oil supplementation on lamb meat characteristics. Meat Sci, 2008; 79: 217-23.

11. Yarosh DB, Galvin JW, Nay SL, Pena AV, Canning MT, Brown DA. Anti-inflammatory activity in skin by biomimetic of evodia rutaecarpa extract from traditional Chinese medicine. J. Dermatol. Sci. 2006; 42: 13-21.

12. Ilie LI, Tudor L, Galis AM. The electrical conductivity of cattle milk and the possibility of mastitis diagnosis in Romania. Lucrari Stiintifice Medicina Veterinara, XLIII2010; (2), 220-7.

13. Khattab HM, El-Basiony AZ, Wakwak SM, Marwan BA. Immune response and productive performance of dairy buffaloes and their offspring supplemented with black seed oil. Iranian Journal of Applied Animal Science, 2011; 1(4): 227-34.

14. Salamon I, Ghanavati M, Khazaei H. Chamomile biodiversity and essential oil qualitative-quantitative characteristics in Egyptian production and Iranian landraces Emir. J. Food Agric. 2010. 22 (1): 59-64

15. Mokhber Dezfouli MR, Mohammadi HR. Nadalian MG, Nazem Bokaee Z, Hadjiakhoondi A, Nikbakht Borujeni GR, Tajik P, Jamshidi
R.2011. Influence of parenteral administration of chamomile (Matricaria recutita L.) extract on colostral IgG absorption in neonatal calves.

16. Tekippe JA, Hristov AN, Heyler KS, Cassidy TW, Zheljazkov VD, Ferreira JFS, Karnati SK, Varga GA. Rumen fermentation and production effects of Origanum vulgare L. in lactating dairy cows. J. Dairy Sci., 2011; 94: 5065-79.

17. Yuan Liguo,Tong Hengmin,Shen Jianzhong. Study on Application of Oil origanum and Flavomycin in Dairy Production. 2004; Feed Industry.

18. AOAC, 2012 Association of Official Analytical Chemists, 19th Ed. Official Methods of Analysis, Washington, DC, USA.

19. NRC (Nutrient Requirements of Dairy Cattle).7th Rev. Ed. National Academy Press, Washington, 2001; DC. USA.

20. Gains WL. 1928. The energy basis of measuring milk yield in dairy cows. University of Lllinois. Agriculture Experiment Station. Bulletin. No. 308.

21. Drew P, Harles CRJS, Trevor B, John L. 2004. Oxford Handbook of Clinical Hematology. 2th Edition, Oxford University Press, USA.

22. SAS. 2004. Statistical Analysis System. SAS statistics. Guide release, version 8.00 TS level OOMO, SAS Institute Inc., Cary, NC.

23. Duncan DB. Multiple range and multiple F tests. Biometrics1955; 11:1-42.

24. Kummer N, Snigh UB, Verma DN. Effect of different levels of dietary protein and energy on growth of male buffalo calves. India J. Anim. Sci., $1981 ; 51: 513$.

25. Ismail AM, Sedki AA, Abdallah AG. Influence of black seed, garlic and onion supplementation on reproductive performance in rabbits. Egyptian. J. Agr. Res. 2003; 81, 1193-207.

26. Khattab HM, Abo El-Nor SAH , Kholif SM , El-Sayed HM , Abd El-Shaffy OH, Saada M. Effect of different additive sources on milk yield and composition of lactating buffaloes. Livestock Sci., 2010; 131(1): 8-14.

27. Sharma A, Prasad S, Singh Y, Bishisth R. Effect of polyherbal preparation supplementation on immunity and udder health of periparturient Karan-Fries crossbred dairy cows. J. Appl. Anim. Res., 2014; 42(2): 217-21.

28. Tizard I. Veterinary Immunology: An Introduction. 4th ed. London: WB Saunders Co, Philadelphia PA, El-Gaafrawy AM, Ahmed N, ElBanna MK, Ibrahim IL. 2000. Effect of Selenium and vitamin $\mathrm{E}$ supplementation on immue response and performance of Baladi calves. Proc. 
Conf. Anim. Prod. In the 21 th Century, Sakha, 1820 April 1992; 267-76.

29. Esonu BO, Fmenalom OO, Udedibie ABI, Herbert U, Ekpor CF, Okolie IC, Iheukwumere FC. Performance and blood chemistry of weaner pigs fed raw mucuna (velvet bean). Tropical animal Production Investigations. 2001; 4: 49-54.

30. EL-Ghousein S. Safaa. Effect of some medicinal plants as feed additives on lactating Awassi ewe performance, milk composition, lamb growth and relevant blood items. Egyptian J. Anim. Prod., 2010; 47(1):37-49.

31. Abo El-Nor SAH, Khattab HM, Al-Alamy HA, Salem FA, Abdou MM. Effect of some medicinal plants seeds in the rations on the productive performance of lactating buffaloes. Int. J. Dairy Sci.2007; 2: 348-55.

32. Singh N, Kumari R, Yadav RS, Akbar MA, Sengupta BP. Effect of some commonly used galactagogue on milk production and biogenic amines in buffaloes. Indian Vet. Med. J., 1991; 15: 20-4
33. Dina A Eisa. Evaluation of somatic cell count and it is relationships with milk yield traits and mastitis in Friesian cow.2007; MSc. Faculty of Agriculture, Kafer El-Shiekh University.

34. Hamann J, Gyodi P. Somatic cells and electrical conductivity in relation to milking frequency. Milchwissensch.2000; 55: 303-7.

35. Milner PKL, Page AW, Hillerton JE. Detection of clinical mastitis by changes in electrical conductivity of fore milk before visible changes in milk. Journal of Dairy Science.1996; 79: 83-6.

36. Kamal RM, Bayoumi MA, Abd El Aal SFA.Correlation between Some direct and indirect test for screen detection of subclinical mastitis. International food research journal, 2014; 21(3), 1249-54.

37. Gaafar HMA, Ayat A, Ragab, El-Reidy KFA. Effect of diet supplemented with pumpkin (Cucurbita moschata) and black seed (Nigella sativa) oils on performance of rabbits: 2-Productive and reproductive performance of does and their offspring. Report Opinion, 2014; 6(1):60-8. 